\title{
Both estrogen and raloxifene protect against $\beta$-amyloid-induced neurotoxicity in estrogen receptor $\alpha$-transfected PC12 cells by activation of telomerase activity via Akt cascade
}

\author{
Botao Du, Masahide Ohmichi, Kazuhiro Takahashi, Jun Kawagoe, \\ Chika Ohshima ${ }^{1}$, Hideki Igarashi, Akiko Mori-Abe, Maki Saitoh, \\ Tsuyoshi Ohta, Akira Ohishi, Masakazu Doshida, Naohiro Tezuka, \\ Toshifumi Takahashi and Hirohisa Kurachi
}

Department of Obstetrics and Gynecology, Yamagata University, School of Medicine, 2-2-2 lidanishi, Yamagata 990-9585, Japan

${ }^{1}$ Division of Nursing, Yamagata University, School of Medicine, 2-2-2 lidanishi, Yamagata 990-9585, Japan

(Requests for offprints should be addressed to M Ohmichi; Email: masa@med.id.yamagata-u.ac.jp)

\begin{abstract}
Although estrogen is known to protect against $\beta$-amyloid $(A \beta)$-induced neurotoxicity, the mechanisms responsible for this effect are only beginning to be elucidated. In addition, the effect of raloxifene on $A \beta$-induced neurotoxicity remains unknown. Here we investigated whether raloxifene exhibits similar neuro-protective effects to estrogen against $A \beta$-induced neurotoxicity and the mechanism of the effects of these agents in PC12 cells transfected with the full-length human estrogen receptor (ER) $\alpha$ gene (PCER). Raloxifene, like $17 \beta$-estradiol $\left(\mathrm{E}_{2}\right)$, significantly inhibited $A \beta$-induced apoptosis in PCER cells, but not in a control line of cells transfected with vector DNA alone (PCCON). Since telomerase activity, the level of which is modulated by regulation of telomerase catalytic subunit (TERT) at both the transcriptional and posttranscriptional levels, is known to be involved in suppressing apoptosis in neurons, we examined the effect of $E_{2}$ and raloxifene on telomerase activity. Although both $\mathrm{E}_{2}$ and
\end{abstract}

raloxifene induced telomerase activity in PCER cells, but not in PCCON cells, treated with $A \beta$, they had no effect on the level of TERT expression. These results suggest that neither $\mathrm{E}_{2}$ nor raloxifene affects the telomerase activity at the transcriptional level. We therefore studied the mechanism by which $\mathrm{E}_{2}$ and raloxifene induce the telomerase activity at the post-transcriptional level. Both $\mathrm{E}_{2}$ and raloxifene induced the phosphorylation of Akt, and pretreatment with a phosphatidylinositol 3-kinase inhibitor, LY294002, attenuated both $\mathrm{E}_{2^{-}}$and raloxifene-induced activation of the telomerase activity. Moreover, both $\mathrm{E}_{2}$ and raloxifene induced both the phosphorylation of TERT at a putative Akt phosphorylation site and the association of nuclear factor $\mathrm{\kappa B}$ with TERT. Our findings suggest that $\mathrm{E}_{2}$ and raloxifene exert neuroprotective effects by telomerase activation via a post-transcriptional cascade in an experimental model relevant to Alzheimer's disease.

Journal of Endocrinology (2004) 183, 605-615

\section{Introduction}

Alzheimer's disease (AD) is one of the most common neuro-degenerative diseases and is the most frequent cause of dementia in the elderly (Bondi et al. 1995). However, the cause of $\mathrm{AD}$ is still unknown and the treatment is therefore only palliative. Compared with men, women appear to be at an increased risk for AD after age 80 to 85 years (Miech et al. 2002, Zandi et al. 2002). Postmenopausal depletion of endogenous estrogens may contribute to this risk. Several clinical trials have shown that women who received estrogen replacement therapy had a reduced risk of developing AD (Tang et al. 1996, Kawas et al. 1997, Paganini-Hill \& Henderson 1996). Estrogens may exert several neuroprotective effects on the aging brain, including inhibition of $\beta$-amyloid $(A \beta)$ formation, stimulation of cholinergic activity, reduction of oxidative stress-related cell damage, and protection against vascular risks (Skoog \& Gustafson 1999). However, the precise mechanism of the neuroprotective mechanism of estrogen has not been elucidated.

Although estrogen replacement therapy is widely prescribed, it may have certain disadvantages because it has been shown to be associated with an increased risk of developing breast and uterine cancers. Thus, because of the need to circumvent the limitations of estrogen replacement therapy, there has been intense interest in the therapeutic use of nonsteroidal selective estrogen receptor 
modulators (SERMs). Raloxifene, which has been classified as a SERM, produces both estrogen-agonistic effects on the bone and lipid metabolism and estrogenantagonistic effects on the uterine endometrium and breast tissue (Delmas et al. 1997, Cummings et al. 1999, Ettinger et al. 1999). Although raloxifene is known to induce neurite outgrowth in estrogen receptor (ER)-positive PC12 cells (Nilsen et al. 1998), the mechanism of neuroprotection by raloxifene has also not been clearly resolved.

Telomerase is a cellular reverse transcriptase that catalyzes the synthesis and extension of telomeric DNA (Greider \& Blackburn 1985, 1989). This enzyme is specifically activated in most malignant tumors but is usually inactive in normal somatic cells, with the result that the ends of chromosomes (telomeres) are progressively shortened during maturation and aging (Kim et al. 1994, Shay \& Bacchetti 1997). Cells require a mechanism to maintain telomere stability in order to overcome replicative senescence, and telomerase activation may therefore be a rate-limiting or critical step in cellular immortality and oncogenesis (Harley \& Villeponteau 1995). Telomerase consists of an RNA subunit and a protein called the catalytic subunit of telomerase (TERT). Although the RNA subunit of the telomerase complex is constitutively expressed in both tumor and normal somatic tissues, the expression of TERT correlates with telomerase activity during cellular differentiation and neoplastic transformation (Kilian et al. 1997, Meyerson et al. 1997, Nakamura et al. 1997). It was recently reported that TERT protects neurons against $A \beta-$ (Zhu et al. 2000) or tropic factor withdrawal- and glutamate (Fu et al. 2000)-induced apoptosis.

There is abundant evidence supporting the idea that the regulation of telomerase in mammalian cells is multifactorial. Telomerase activity can be regulated by modulating both the expression and phosphorylation of TERT. The region surrounding Ser-824 in human (h) TERT conforms to a consensus sequence for phosphorylation by Akt, and Akt kinase enhances the human telomerase activity through phosphorylation of hTERT (Kang et al. 1999). In addition, it was recently reported that estrogen protects against A $\beta$ - (Zhang et al. 2001) or glutamate (Honda et al. 2000)-induced neurotoxicity via the activation of Akt. Moreover, pro-atherogenic factors induce telomerase inactivation in endothelial cells through an Akt-dependent mechanism (Breitschopf et al. 2001) and we have reported that both estrogen (Hisamoto et al. 2001a) and raloxifene (Hisamoto et al. 2001b) induce endothelial nitric oxide synthase (eNOS) activation via an Akt cascade. Thus, it appears possible that estrogen and raloxifene exert neuroprotective effects by enhancing the human telomerase activity through an Akt cascade.

These findings led us to examine whether raloxifene has a neuroprotective function, as estrogen does, and whether the effects are induced by enhancing human telomerase activity through an Akt cascade.

\section{Materials and Methods}

\section{Materials}

Synthetic A $\beta$ (human, 25-35), the cytotoxic sequence between amino acid residues 25 and $35 \mathrm{~A} \beta$, was purchased from Peptide Institute (Osaka, Japan). LipofectAMINE Plus reagent and G418 (geneticin) were purchased from Invitrogen (Carlsbad, CA, USA). Raloxifene analog, LY117018, was a kind gift from Eli Lilly Research Laboratories (Indianapolis, IN, USA). 17 $\beta$-estradiol $\left(\mathrm{E}_{2}\right)$, dimethyl sulfoxide (DMSO), and rabbit IgG (immunoglobulin G) were purchased from Sigma. LY294002 was purchased from Calbiochem (San Diego, CA, USA). The anti-phospho-Akt, phospho-Akt substrate, and Akt were obtained from Cell Signaling (Beverly, MA, USA). The anti-nuclear factor kappaB (NFkB) p65, TERT and ER $\alpha$ antibodies were obtained from Santa Cruz Biotechnology, Inc. (Santa Cruz, CA, USA).

\section{Cell culture and experimental conditions}

PC12 rat pheochromocytoma cells transfected with the full-length human ER $\alpha$ gene (PCER) or with vector DNA alone (PCCON) were a kind gift from Dr Monica M Oblinger (Chicago Medical School, North Chicago, IL, USA). The cells were grown in Dulbecco's modified Eagle's medium (DMEM) supplemented with 10\% fetal calf serum, 100 units $/ \mathrm{ml}$ penicillin $\mathrm{G}$ sodium, and $100 \mu \mathrm{g} / \mathrm{ml}$ streptomycin sulfate in the presence of $5 \% \mathrm{CO}_{2}$ at $37^{\circ} \mathrm{C}$.

\section{Apoptosis assay}

Five thousand cells/well were placed into extracellular matrix-coated chamber slides in DMEM with 10\% FBS, and then starved for $48 \mathrm{~h}$ in phenol red-free DMEM with 10\% charcoal-stripped serum (CSS). After starvation, some cells were treated with various materials. Apoptosis was assessed by terminal deoxynucleotidyl transferasemediated dUTP nick end-labeling (TUNEL) staining using an Apoptosis In Situ Detection kit (Wako, Osaka, Japan), and the cells undergoing programmed cell death were counted in five separate fields per experiment.

\section{Stretch PCR assay}

For quantitative analysis of telomerase activity, stretch PCR assays were performed using the Telochaser system according to the manufacturer's protocol (Toyobo, Tokyo, Japan) as described previously (Kyo et al. 1999, Kawagoe et al. 2003, Kimura et al. 2004). Briefly, we resuspended the cell pellets in cell lysis buffer so that an aliquot of $20 \mu \mathrm{l}$ corresponded to 25000 cells. After incubation for $60 \mathrm{~min}$ at $37^{\circ} \mathrm{C}$, the DNA product was isolated and 26 cycles of 


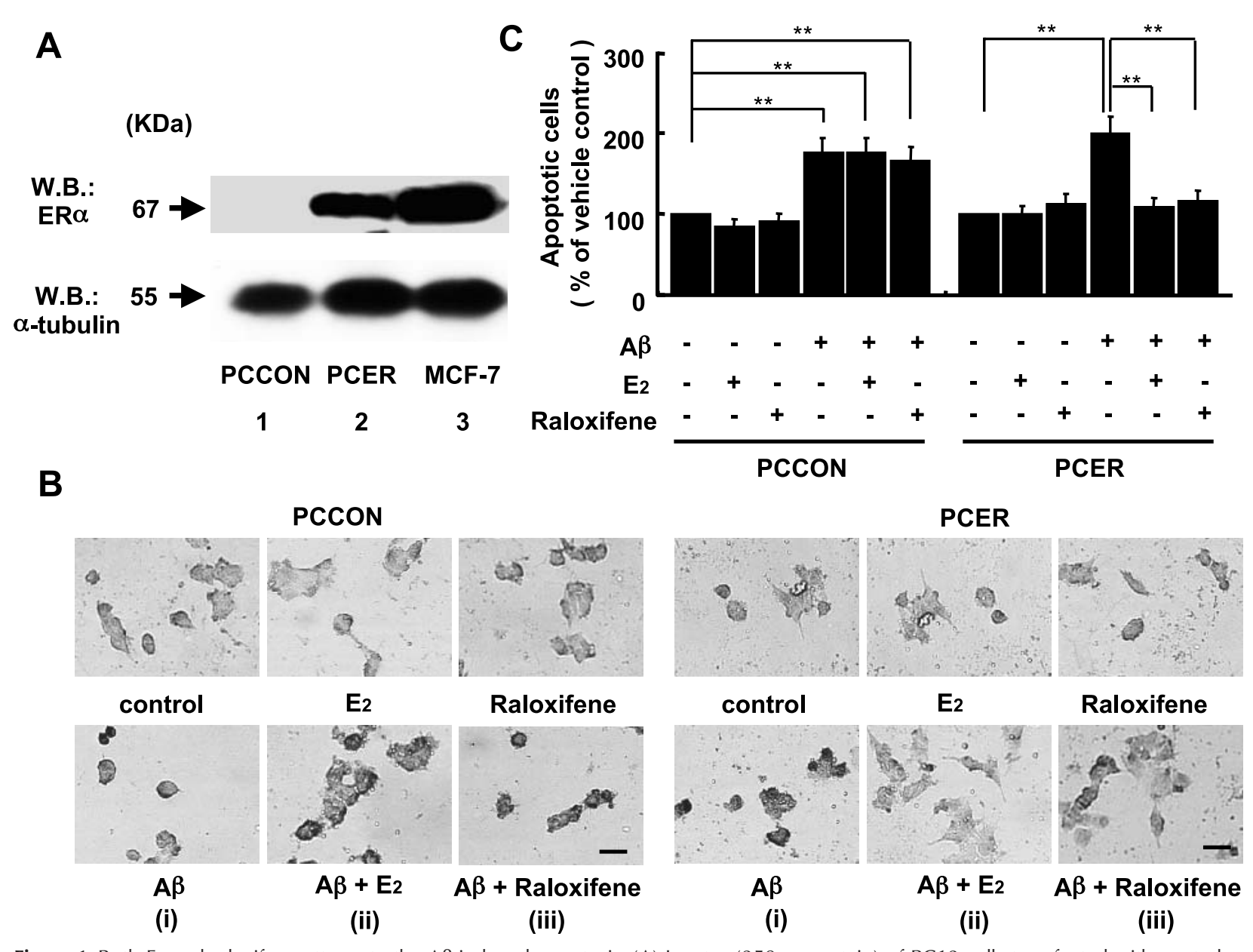

Figure 1 Both $E_{2}$ and raloxifene attenuate the $A \beta$-induced apoptosis. (A) Lysates (250 $\mu$ g protein) of PC12 cells transfected with control vector (PCCON) (lane 1), ER $\alpha$ vector (PCER) (lane 2), or MCF-7 (lane 3) cells were resolved by $8 \%$ SDS-PAGE and subjected to Western blotting (W.B.) with anti-ER $\alpha$ (upper panel) or anti- $\alpha$-tubulin (lower panel) antibody. The positions of molecular weight markers are noted on the left. Experiments were repeated three times with essentially similar results. (B) PCCON (left) and PCER (right) cells were grown on a chamber slide. Cells were pretreated with (lower panels) or without (upper panels) $20 \mu \mathrm{M} \mathrm{A} \beta$ followed by treatment with vehicle control (i), $10^{-8} \mathrm{ME}_{2}$ (ii), or $10^{-8} \mathrm{M}$ raloxifene (iii) for $24 \mathrm{~h}$. Cells were stained by the TUNEL method using a kit for detection of apoptosis in situ. Apoptotic cells were stained darker and were counted by visual inspection under a light microscope. Methyl green solution $(0 \cdot 5 \%)$ was also used for counterstaining. Magnification: $\times 200$. Bar $=100 \mu \mathrm{m}$. (C) The percentage of apoptotic cells in 100 examined cells is shown as the proportion of apoptotic cells in the cultures treated with vehicle control set arbitrarily at $100 \%$. The ratio of apoptotic cells is shown as a percentage of that of the vehicle control group. Values shown represent the mean \pm s.E. from five separate experiments. Significant differences are indicated by asterisks, ${ }^{*} P<0 \cdot 01$.

PCR amplification were performed at $95^{\circ} \mathrm{C}$ for $30 \mathrm{~s}$, at $68^{\circ} \mathrm{C}$ for $30 \mathrm{~s}$ and at $72{ }^{\circ} \mathrm{C}$ for $45 \mathrm{~s}$. The PCR products were electrophoresed on a $7 \%$ polyacrylamide gel and visualized with SYBR Green I Nucleic Acid Gel Stain (FMC BioProducts, Rockland, ME, USA). To monitor the efficiency of PCR amplification, $10 \mathrm{ng}$ of an internal control consisting of phage DNA (Toyobo) together with 50 pmol of specific primers (Toyobo) were added to the PCR mixture per reaction. Band intensity was measured using NIH Image software developed at the US National Institute of Health and available on the internet at http:/ rsb.info.nih.gov/nih-image/.

\section{RT-PCR analysis}

Total cellular RNA was isolated using Tri-Reagent (Molecular Research Center, Inc., Cinncinati, OH, USA). The expression of rat TERT (rTERT) mRNA and glyceraldehyde-3-phosphate dehydrogenase (GAPDH) mRNA were analyzed by semiquantitative RT-PCR amplification as described previously (Kyo et al. 1999). Briefly, rTERT mRNAs were amplified using the primer pair $5^{\prime}$-GGCTCTTCTTCTACCGTAAG-3' and $5^{\prime}-$ TGATGCTTGACCTCCTCTTG-3'. cDNA was synthesized from $1 \mu \mathrm{g}$ RNA using an RNA PCR kit version 2 


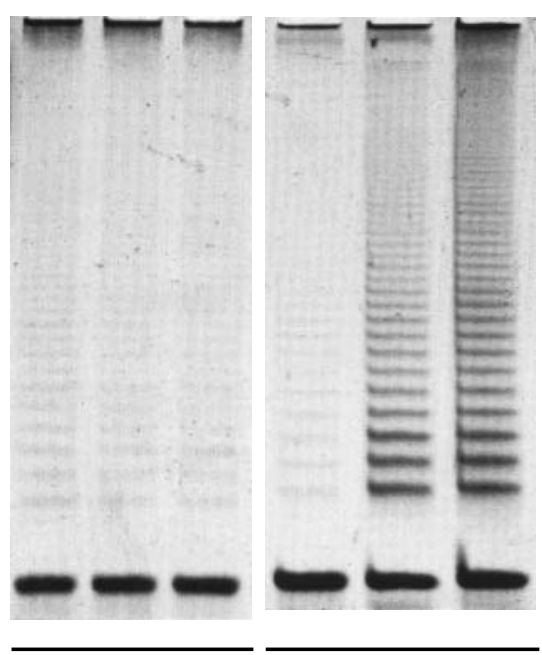

PCCON PCER

E2 Raloxifene

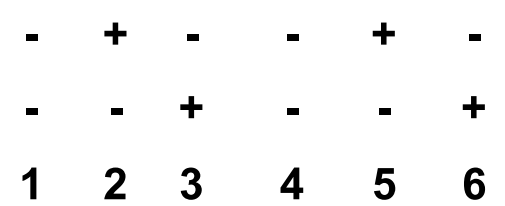

Figure 2 Both $E_{2}$ and raloxifene increase the telomerase activity. PCCON (left panel) and PCER (right panel) cells pretreated with $20 \mu \mathrm{M} \mathrm{A} \beta$ were incubated with vehicle control (lanes 1 and 4), $10^{-8} \mathrm{M} \mathrm{E}_{2}$ (lanes 2 and 5), or $10^{-8} \mathrm{M}$ raloxifene (lanes 3 and 6) for $24 \mathrm{~h}$. The telomerase activity in each preparation was detected by the stretch PCR assay. A representative example of an experiment that was repeated three times is shown.

(TaKaRa, Ohtsu, Japan) with random primers. Serially diluted cDNA reverse-transcribed from $1 \mu \mathrm{g}$ RNA was first amplified by RT-PCR to generate standard curves. The correlation between band intensity and dose of cDNA template was linear under the conditions described below. Typically, $2 \mu \mathrm{l}$ aliquots of the reverse-transcribed cDNA were amplified by 29 cycles of PCR in $50 \mu \mathrm{l}$ of $1 \times$ buffer (10 mM Tris- $\mathrm{HCl}$ (pH 8.3), $2.5 \mathrm{mM} \mathrm{MgCl}_{2}$, and $50 \mathrm{mM}$ $\mathrm{KCl}$ ) containing $1 \mathrm{mM}$ each of dATP, dCTP, dGTP and dTTP, 2.5 units Taq DNA polymerase (TaKaRa), and each specific primer at $0.2 \mu \mathrm{M}$. Each cycle consisted of denaturation at $94{ }^{\circ} \mathrm{C}$ for $60 \mathrm{~s}$, annealing at $52{ }^{\circ} \mathrm{C}$ for $60 \mathrm{~s}$, and extension at $72{ }^{\circ} \mathrm{C}$ for $90 \mathrm{~s}$. PCR products were resolved by electrophoresis in a $1 \%$ agarose gel. The efficiency of cDNA synthesis from each sample was estimated by PCR with GAPDH-specific primers as described previously (Kyo et al. 1999).

\section{Western blot analysis}

Cells were incubated in phenol red-free medium without serum for $48 \mathrm{~h}$ and then treated with various agents. They were then washed twice with phosphate-buffered saline and lysed in ice-cold HNTG buffer (50 mM HEPES,
$\mathrm{pH}$ 7.5, $150 \mathrm{mM} \mathrm{NaCl}, 10 \%$ glycerol, 1\% Triton X-100, $1.5 \mathrm{mM} \mathrm{MgCl}_{2}, 1 \mathrm{mM}$ EDTA, $10 \mathrm{mM}$ sodium pyrophosphate, $100 \mu \mathrm{M}$ sodium orthovanadate, $100 \mathrm{mM}$ $\mathrm{NaF}, 10 \mu \mathrm{g} / \mathrm{ml}$ aprotinin, $10 \mu \mathrm{g} / \mathrm{ml}$ leupeptin, and $1 \mathrm{mM}$ phenylmethylsulfonyl fluoride) (Mabuchi et al. 2002). The lysates were centrifuged at $12000 \times \boldsymbol{g}$ at $4{ }^{\circ} \mathrm{C}$ for $15 \mathrm{~min}$, and the protein concentrations of the supernatants were determined using the Bio-Rad protein assay reagent. Equal amounts of proteins were separated by SDS-PAGE and transferred to nitrocellulose membranes. Blocking was done in 5\% skim milk in $1 \times$ Tris-buffered saline (TBS). Western blot analyses were performed with various specific primary antibodies. For detection of phosphorylated rTERT or association of rTERT with Akt, and the association of TERT with NFKB, cell lysates were prepared using HNTG buffer. Lysates were incubated with anti-TERT antibody overnight and then immunoprecipitated for $2 \mathrm{~h}$ with protein A-Sepharose. Immune complexes were washed with ice-cold HNTG buffer, electrophoresed, and analyzed by immunoblotting with anti-phospho-Akt substrate antibody or anti-NFKB p65 antibody. Immunoreacted bands in the immunoblots were visualized with horseradish peroxidase-coupled goat antirabbit or anti-mouse immunoglobulin using the enhanced chemiluminescence Western blotting system.

\section{Statistics}

Statistical analysis was performed by Student's $t$-test, and $P<0 \cdot 01$ was considered significant. Data are expressed as the mean \pm S.E.

\section{Results}

Both $E_{2}$ and raloxifene attenuate $A \beta$-induced apoptosis

Since it has been reported that both estrogen (Bonnefont et al. 1998) and raloxifene (Nilsen et al. 1998) induce neurite outgrowth in ER-positive PC12 cells, we examined whether estrogen or raloxifene attenuates A $\beta$-induced apoptosis using ER $\alpha$-transfected PC12 cells (PCER), whose parent cells are known to express ER $\beta$ but not ER $\alpha$ (Bonnefont et al. 1998, Gollapudi \& Oblinger 2001). The MCF-7 human breast cancer cell line was used as a positive control to detect ER $\alpha$. Western blotting analysis confirmed that PCER and MCF-7 cells expressed ER $\alpha$, while PCCON cells (cells transfected with vector alone) did not (Fig. 1A). Cultured cells were grown in the presence of $10 \%$ CSS (Fig. 1B, upper panel) or $10 \%$ CSS $+\mathrm{A} \beta$ (Fig. 1B, lower panel) with or without $10^{-8} \mathrm{M} \mathrm{E}_{2}$ or $10^{-8} \mathrm{M}$ raloxifene. Cultured cells were stained by the TUNEL method. Apoptotic cells were stained brown (Fig. 1B), and were counted under a light microscope. Although $A \beta$ induced apoptosis in both PCCON and PCER cells, $10^{-8} \mathrm{M} \mathrm{E}_{2}$ or $10^{-8} \mathrm{M}$ 
A
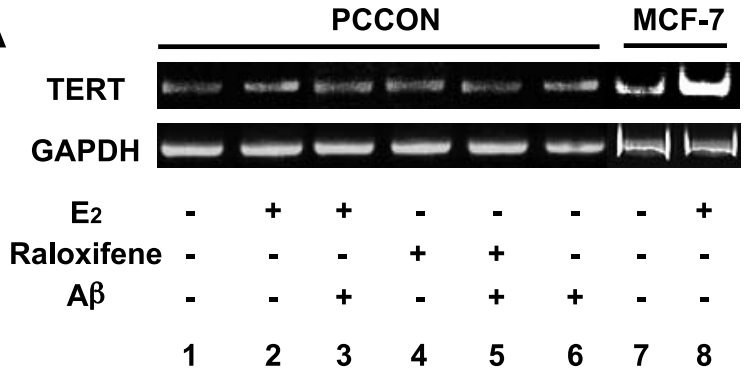

B

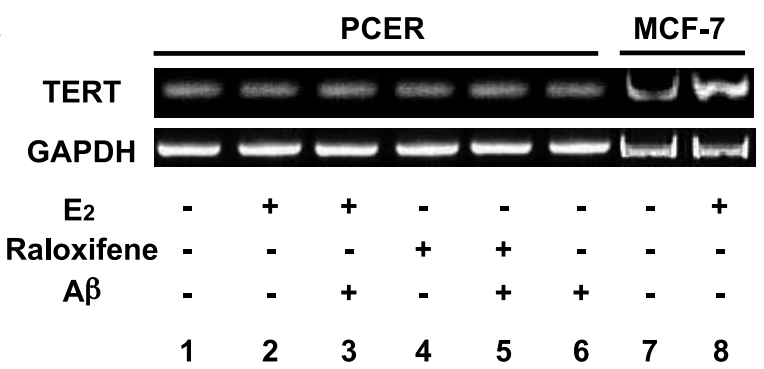

Figure 3 The effect of $E_{2}$ and raloxifene on the mRNA expression of TERT. PCCON (A) and PCER (B) cells were treated with vehicle control (lane 1), $10^{-8} \mathrm{M} \mathrm{E}_{2}$ (lane 2), $10^{-8} \mathrm{M} \mathrm{E}_{2}+20 \mu \mathrm{M} \mathrm{A} \beta$ (lane 3 ), $10^{-8} \mathrm{M}$ raloxifene (lane 4 ), $10^{-8} \mathrm{M}$ raloxifene $+20 \mu \mathrm{M}$ $\mathrm{A} \beta$ (lane 5), or $20 \mu \mathrm{M} \mathrm{A} \beta$ (lane 6) for $24 \mathrm{~h}$. MCF-7 cells were treated with vehicle control (lane 7) or $10^{-8} \mathrm{M} \mathrm{E}_{2}$ (lane 8) for $24 \mathrm{~h}$. RNA was extracted and RT-PCR assays were performed to detect TERT mRNA expression. GAPDH, glyceraldehyde-3phosphate dehydrogenase. raloxifene significantly inhibited the $A \beta$-induced apoptosis in PCER cells treated with $A \beta$, but not in PCCON cells treated with $A \beta$ (Fig. 1B, C). These data suggest the possibility that both $\mathrm{E}_{2}$ and raloxifene might attenuate the $\mathrm{A} \beta$-induced apoptosis in the presence of ER $\alpha$.

\section{Both $E_{2}$ and raloxifene induce telomerase activity}

Since TERT has been reported to protect neurons against A $\beta$-induced apoptosis (Zhu et al. 2000), we examined the effects of estrogen and raloxifene on telomerase activity. $\mathrm{A} \beta$-treated PCCON and PCER cells were treated with $10^{-8} \mathrm{M} \mathrm{E}_{2}$ or $10^{-8} \mathrm{M}$ raloxifene and were subjected to quantitative stretch PCR assays to assess the telomerase activity. It appeared that both $\mathrm{E}_{2}$ and raloxifene induced the telomerase activity in PCER cells treated with $A \beta$, but not in PCCON cells treated with $A \beta$ (Fig. 2).

The effects of $E_{2}$ and raloxifene on the expression of TERT

Since the telomerase activity is known to be modulated by regulation of the level of telomerase catalytic subunit (TERT) at both the transcriptional and posttranscriptional levels, semiquantitative RT-PCR assays were performed to examine whether the activation of telomerase by estrogen or by raloxifene was due to up-regulation of the expression of TERT mRNA. Although treatment of MCF-7 cells with $10^{-8} \mathrm{M} \mathrm{E}_{2}$ for
A

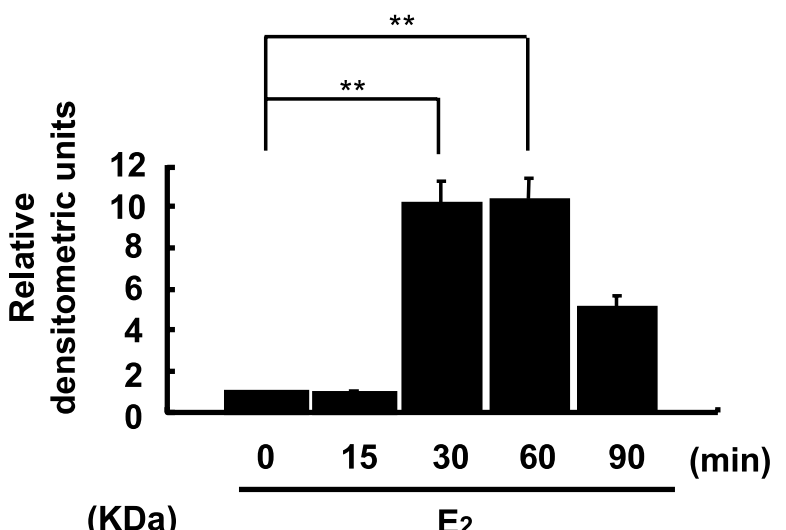

W.B.:

(KDa)

E2

\section{W.B.:}

A-Akt
B
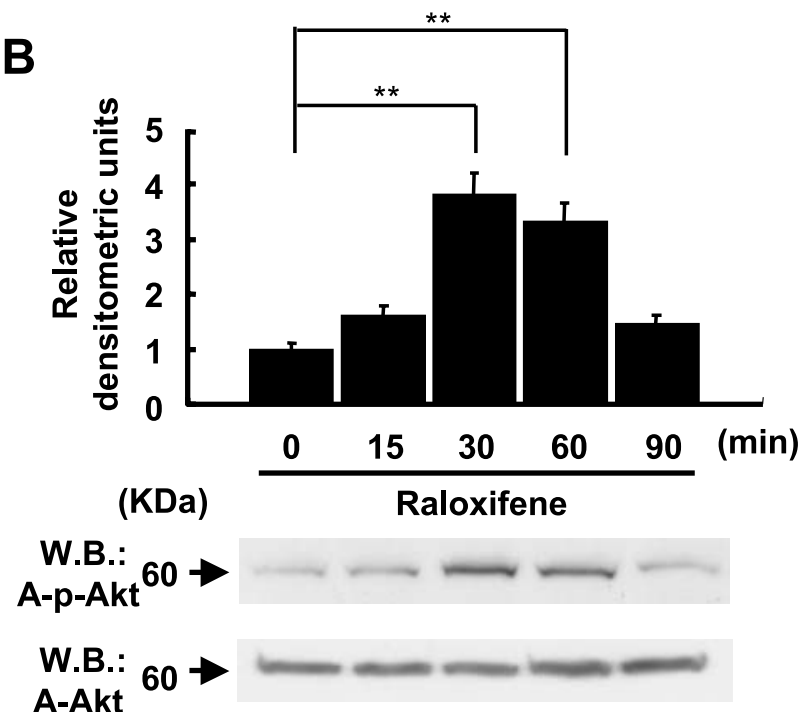

Figure 4 Both $E_{2}$ and raloxifene induce the phosphorylation of Akt. PCER cells were treated with $10^{-8} \mathrm{M} \mathrm{E}_{2}$ (A) or $10^{-8} \mathrm{M}$ raloxifene (B) for the indicated times, and then harvested and used to prepare cell lysates. The lysates were subjected to SDS-PAGE and blotted with anti-phospho-Akt (A-p-Akt; middle panels) or anti-Akt (A-Akt; lower panels) antibody. The positions of molecular weight markers are noted on the left. Relative densitometric units of the p-Akt bands are shown in the upper panel, with the density of the vehicle control bands $(0 \mathrm{~min})$ set arbitrarily at $1 \cdot 0$. Values shown represent the mean \pm S.E. from at least three separate experiments. Significant differences are indicated by asterisks, ${ }^{* *} P<0 \cdot 01$. W.B., Western blotting. 


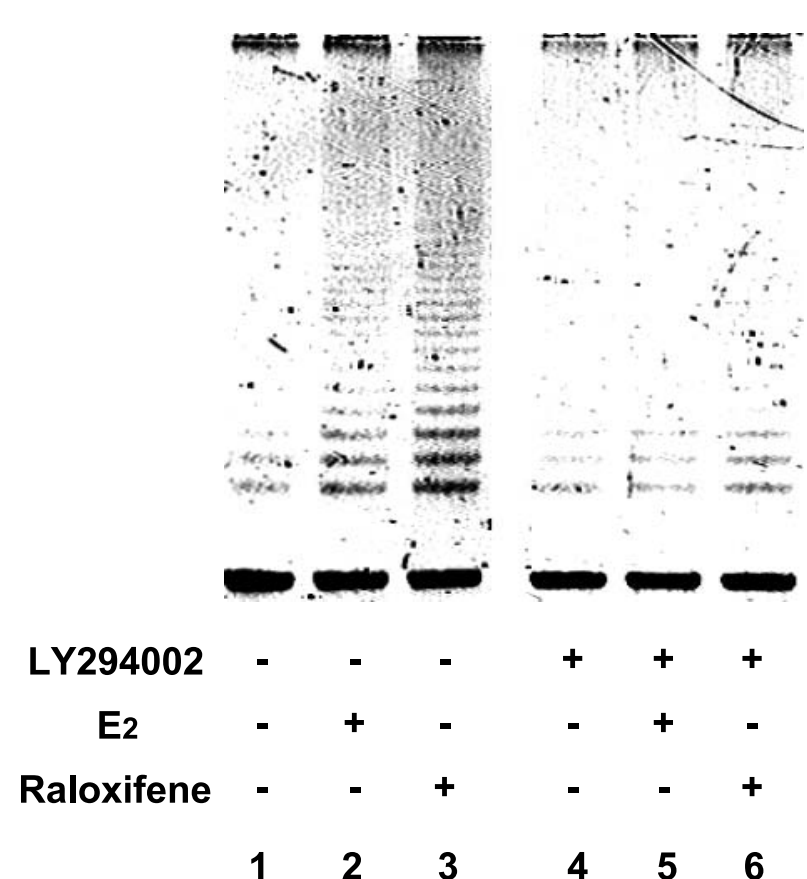

Figure 5 Both $E_{2}$ and raloxifene induce the telomerase activity via a PI3K/Akt cascade. PCER cells pretreated with $20 \mu \mathrm{M}$ A $\beta$ were treated with $10^{-8} \mathrm{M} \mathrm{E}_{2}$ (lanes 2 and 5) or $10^{-8} \mathrm{M}$ raloxifene (lanes 3 and 6 ) for $24 \mathrm{~h}$ in the presence (lanes 4-6) or absence (lanes 1-3) of LY294002 and were subjected to quantitative stretch PCR assays to assess the telomerase activity.

$24 \mathrm{~h}$ induced the expression of TERT mRNA (Fig. 3A and $\mathrm{B}$, lanes 7 and 8), treatment of PCCON (Fig. 3A) or PCER (Fig. 3B) cells with $10^{-8} \mathrm{M} \mathrm{E}_{2}$ or $10^{-8} \mathrm{M}$ raloxifene in the presence or absence of $A \beta$ for $24 \mathrm{~h}$ seemed to exhibit no change in the expression of TERT mRNA, suggesting the possibility that these agents might induce the telomerase activity by a mechanism without influencing the transcriptional level, as shown previously for the cytokine-induced telomerase activity (Akiyama et al. 2002).

\section{Both $E_{2}$ and raloxifene induce the phosphorylation of $A k t$}

Telomerase activity may also be regulated by posttranslational modifications of the enzyme. It has been reported that the region surrounding Ser-824 in hTERT conforms to a consensus sequence for phosphorylation by Akt, and that Akt kinase enhances human telomerase activity through phosphorylation of hTERT (Kang et al. 1999). In addition, it was reported that estrogen protects against $A \beta$-induced neurotoxicity by activation of Akt (Zhang et al. 2001). Therefore, we next examined whether $E_{2}$ or raloxifene induces the phosphorylation of Akt. The cells were treated with $\mathrm{E}_{2}$ or raloxifene for various times, and the cell lysates were resolved by SDS-PAGE and then subjected to Western blotting with anti-phospho-Akt antibody or anti-Akt antibody. Although $\mathrm{E}_{2}$ and raloxifene did not affect the expression of Akt (Fig. 4A, B, bottom panel), they induced transient phosphorylation of Akt (Fig. 4A, B, top and middle panels).

Both $E_{2}$ and raloxifene induce telomerase activity via the phosphatidylinositol 3-kinase (PI3K)/Akt cascade

To examine whether the PI3K/Akt cascade is involved in the $\mathrm{E}_{2^{-}}$and raloxifene-induced telomerase activation, $\mathrm{A} \beta$-treated PCER cells were treated with $10^{-8} \mathrm{M} \mathrm{E}_{2}$ or $10^{-8} \mathrm{M}$ raloxifene in the presence or absence of LY294002 and subjected to quantitative stretch PCR assays to assess the telomerase activity. LY294002 apparently attenuated both $\mathrm{E}_{2^{-}}$and raloxifene-induced telomerase activation in A $\beta$-treated PCER cells (Fig. 5), suggesting the possibility that the PI3K/Akt cascade might be involved in the induction of telomerase activity by $\mathrm{E}_{2}$ and raloxifene.

Both $E_{2}$ and raloxifene induce the phosphorylation of TERT at a putative Akt phosphorylation site

We examined whether $\mathrm{E}_{2}$ or raloxifene induces the phosphorylation of TERT at a putative Akt phosphorylation site. Cells were treated with $\mathrm{E}_{2}$ or raloxifene for various times and then used to prepare lysates that were immunoprecipitated with anti-TERT antibody and then subjected to Western blotting with anti-phospho-Akt substrate antibody or anti-TERT antibody (Fig. 6). The increase in TERT phosphorylation induced by $\mathrm{E}_{2}$ or raloxifene at a putative Akt phosphorylation site reached a plateau at $30 \mathrm{~min}$ and declined thereafter (Fig. 6, top and middle panels). The anti-TERT Western blot analysis showed equal precipitation of TERT protein in the various lysates (Fig. 6, bottom panel).

Both $E_{2}$ and raloxifene induce the association of $N F \kappa B$ with TERT

One possible mechanism for the post-translational modification of telomerase is via the interaction of TERT with accessory proteins. Recently, NFKB was reported to be a post-translational modifier of telomerase that functions by controlling the intracellular localization of hTERT (Akiyama et al. 2003). Therefore, we examined whether $\mathrm{E}_{2}$ or raloxifene induces the association of NFKB p65 with TERT. Cells were treated with $\mathrm{E}_{2}$ or raloxifene for the indicated times and used to prepare cell lysates that were immunoprecipitated with anti-TERT antibody and then subjected to Western blotting with anti-NFKB p65 antibody or anti-TERT antibody. $\mathrm{E}_{2}$ and raloxifene did not affect the expression of hTERT (Fig. 7, bottom panel), but 


\section{I.P.: A-TERT}

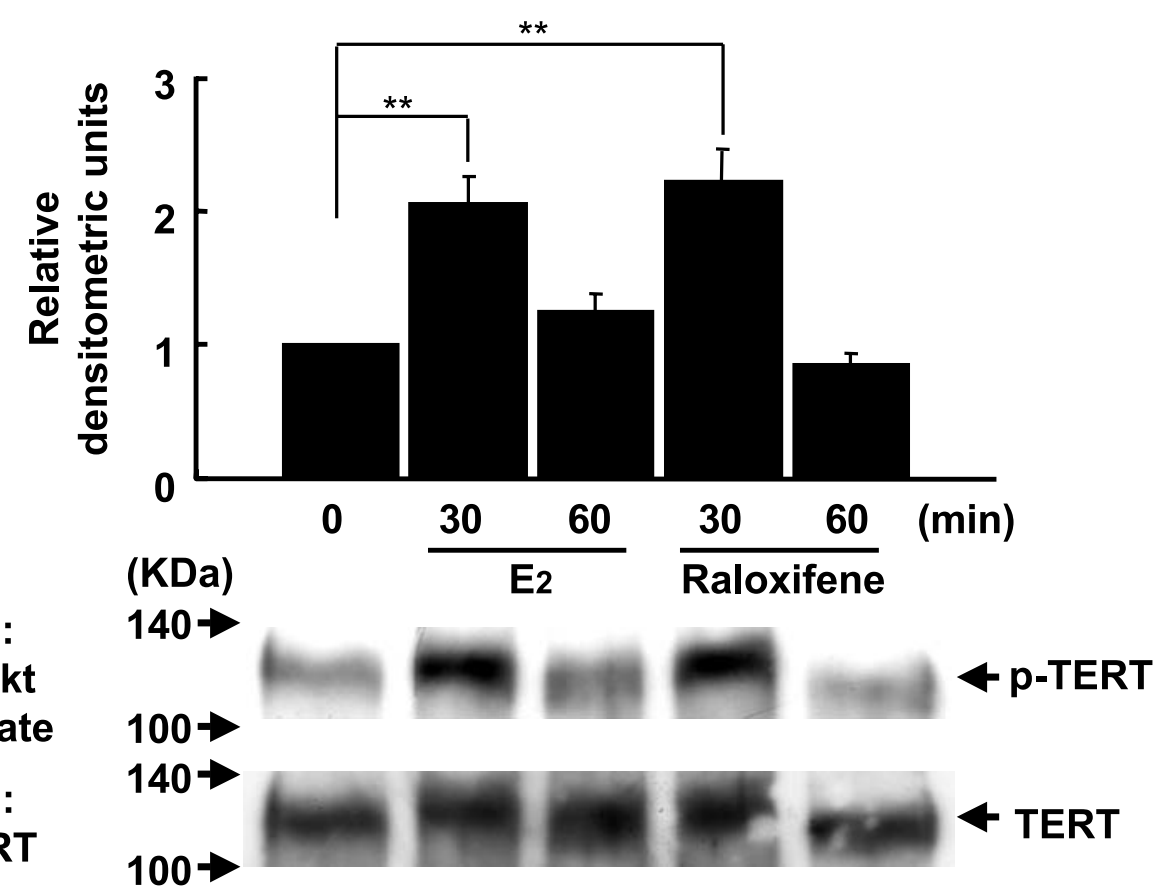

Figure 6 Both $E_{2}$ and raloxifene induce the phosphorylation of TERT at a putative Akt phosphorylation site. PCER cells were treated with $10^{-8} \mathrm{ME}_{2}$ or $10^{-8} \mathrm{M}$ raloxifene for the indicated times, and then harvested and lysed. The lysates were subjected to immunoprecipitation with anti-hTERT antibody (A-TERT). The immunoprecipitates were subjected to SDS-PAGE, and the separated proteins were transferred to a nitrocellulose membrane and blotted with anti-phospho-Akt substrate (A-p-Akt; middle panel) or anti-hTERT (lower panel) antibody. The positions of molecular weight markers are noted on the left. Relative densitometric units of the p-hTERT bands are shown in the upper panel, with the density of the vehicle control bands $(0 \mathrm{~min})$ set arbitrarily at $1 \cdot 0$. Values shown represent the mean \pm S.E. from at least three separate experiments. Significant differences are indicated by asterisks, ${ }^{*} P<0 \cdot 01$. I.P., immunoprecipitation; W.B., Western blotting,

the association of TERT with NFKB p65 was upregulated by $\mathrm{E}_{2}$ and raloxifene (Fig. 7, top and middle panels).

\section{Discussion}

One of the two novel findings in this study was that raloxifene, like estrogen, protects neurons against $A \beta$ induced apoptosis by activation of Akt in PC12 cells transfected with ER $\alpha$. Correlative studies with raloxifene and Akt in the brain have not been performed, but we previously demonstrated that raloxifene rapidly activates Akt in vascular endothelial cells (Hisamoto et al. 2001b), suggesting that a similar regulation in the brain by raloxifene is possible. Another finding we made here was that the up-regulation of telomerase activity induced by both estrogen and raloxifene via phosphorylation of hTERT at a putative Akt phosphorylation site and association of hTERT with NFKB might be involved in their neuroprotective functions. Thus, Akt may have an important role in the neuroprotective functions of both estrogen and raloxifene (Fig. 8).

The Women's Health Initiative Memory Study (WHIMS) has recently shown that estrogen plus progestin therapy did not prevent cognitive impairment and did not improve cognitive function (Rapp et al. 2003, Shumaker et al. 2003). It was also reported that raloxifene treatment for 3 years did not affect overall cognitive scores in postmenopausal women with osteoporosis (Yaffe et al. 2001). Since the participants in these studies were elderly postmenopausal women aged 65 years or older, it remains possible that either estrogen or raloxifene may be useful in younger postmenopausal women who are in the latent pathogenetic stages of $\mathrm{AD}$ before extensive damage to the integrity of the brain occurs.

We examined the mechanism of the estrogen- and raloxifene-induced post-transcriptional up-regulation of telomerase activity in this study. Phosphorylation of TERT protein is one mechanism of telomerase activation. 


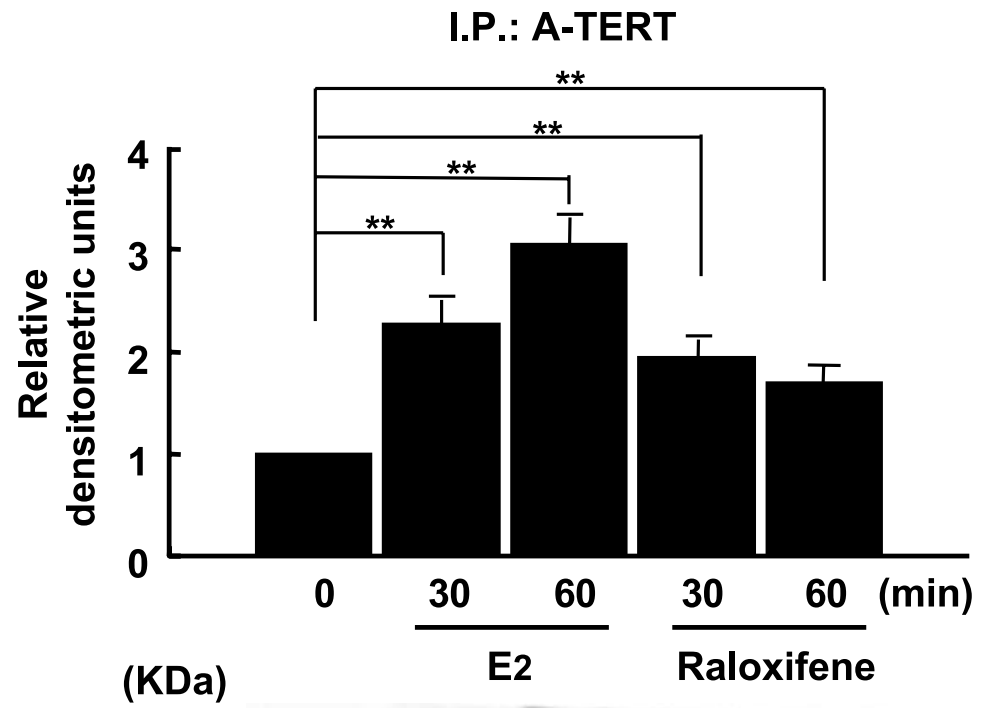

\section{W.B.: A-NFKB p 65

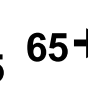 \\ W.B.: A-TERT \\ 140 $100 \rightarrow$}

Figure 7 Both $E_{2}$ and raloxifene induce the association of NFKB with TERT. PCER cells were treated with $10^{-8} \mathrm{ME}_{2}$ or $10^{-8} \mathrm{M}$ raloxifene for the indicated times, and then harvested and lysed. The lysates were subjected to immunoprecipitation with anti-hTERT (A-TERT) antibody. The immunoprecipitates were subjected to SDS-PAGE, and the separated proteins were transferred to a nitrocellulose membrane and blotted with anti-NFkB p65 antibody (A-NFkB p65; middle panel) or anti-hTERT (lower panel) antibody. The positions of molecular weight markers are noted on the left. Relative densitometric units of the NFkB p65 bands are shown in the upper panel, with the density of the vehicle control bands $(0 \mathrm{~min})$ set arbitrarily at 1·0. Values shown represent the mean \pm S.E. from at least three separate experiments. Significant differences are indicated by asterisks, ${ }^{* *} P<0 \cdot 01$. I.P., immunoprecipitation; W.B., Western blotting.

Telomerase activity in human breast cancer cells is markedly inhibited by treatment with protein phosphatase $2 \mathrm{~A}$ (Li et al. 1997). Some protein kinases, such as Akt kinase and protein kinase $\mathrm{C}$, have been reported to mediate the phosphorylation of TERT protein, leading to telomerase activation (Li et al. 1998, Kang et al. 1999). The region surrounding Ser-824 in hTERT conforms to a consensus sequence for phosphorylation by Akt (Kang et al. 1999). In the present study, both estrogen and raloxifene-induced telomerase activity seems to be dependent on the phosphorylation of TERT at a putative Akt phosphorylation site (Fig. 5) and independent of the amount of TERT expression (Fig. 3), as shown previously in the case of cytokine-induced telomerase activity (Akiyama et al. 2002).

Moreover, NFKB p65 was recently reported to be a post-translational modifier of telomerase that functions by controlling the intracellular localization of hTERT (Akiyama et al. 2003, Kawagoe et al. 2003). We found that the association of TERT with NFKB p65 was upregulated by both $\mathrm{E}_{2}$ and raloxifene in PCER cells (Fig. 7). This result leads us to speculate that NFKB p65 in neural cells may play a pivotal role in regulating telomerase activity by modulating the nuclear translocation of TERT. As we have demonstrated that nuclear translocation of TERT is necessary for $E_{2}$-induced telomerase activity in MCF-7 cells (Kawagoe et al. 2003), we are also examining whether $\mathrm{E}_{2}$ and raloxifene induce nuclear translocation of TERT in PCER cells.

Two ER isoforms, ER $\alpha$ and ER $\beta$, are expressed in the adult brain. Which ER is involved in the neuroprotection by estrogen and raloxifene? To elucidate the individual ER subtype involved in $\mathrm{E}_{2}$-mediated neuroprotection in vivo, specific ER knockout mice models have been used, including ER $\alpha$ knockout mice (ERKO) and ER $\beta$ knockout mice $(\beta E R K O)$. $E_{2}$ failed to protect the brain of ovariectomized ERKO mice (Dubal et al. 2001). In contrast, $\mathrm{E}_{2}$ protected the brain of ovariectomized $\beta E R K O$ mice in a manner similar to that observed in ovariectomized wild-type mice (Dubal et al. 2001). Moreover, we have shown that estrogen and raloxifene induce the activation of Akt via $\mathrm{ER} \alpha$, but not $\mathrm{ER} \beta$, in vascular endothelial (Hisamoto et al. 2001a,b) and human ovarian 


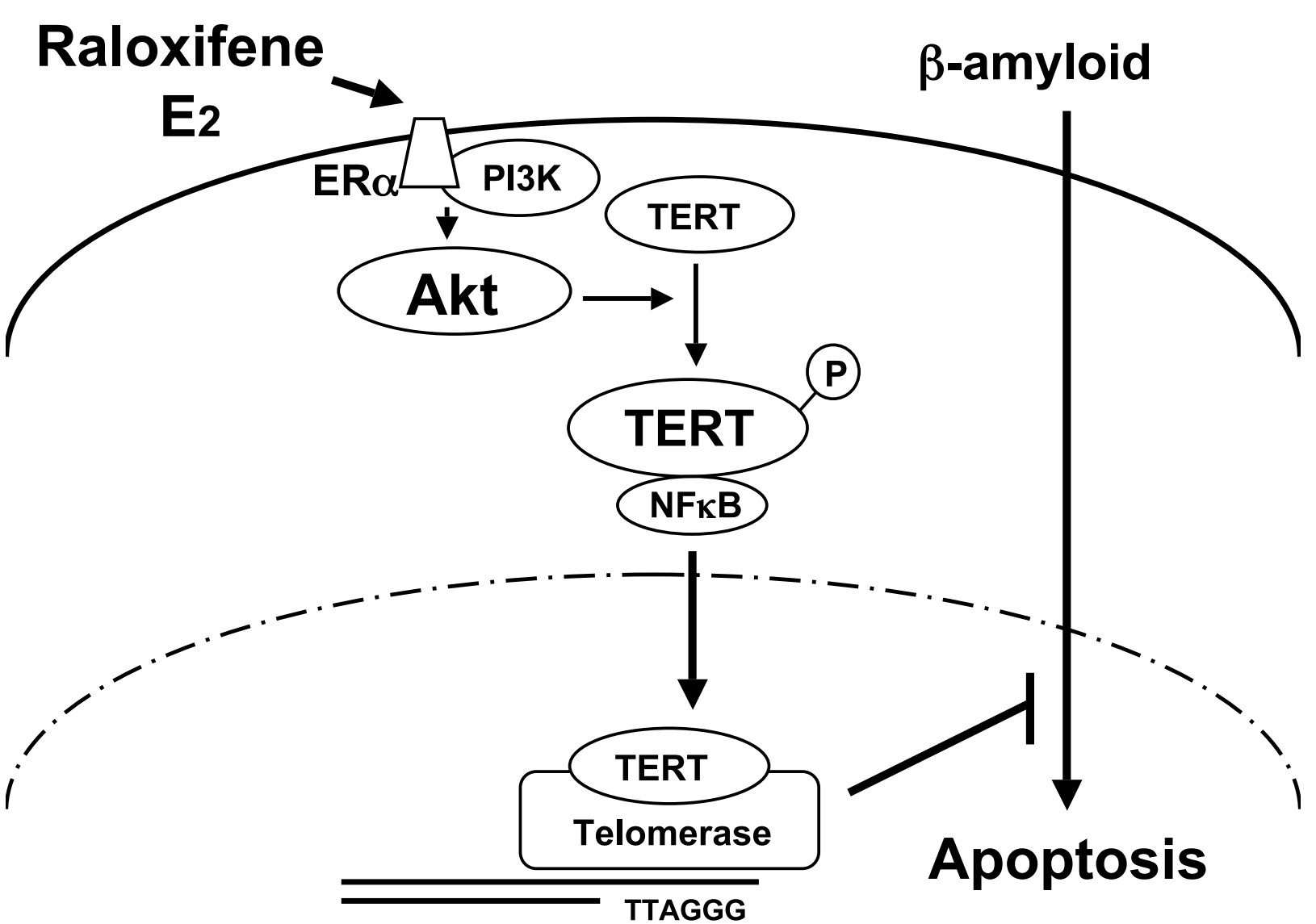

Figure 8 Molecular mechanisms of both $\mathrm{E}_{2}$ and raloxifene increase the telomerase activity in ER $\alpha$-transfected PC12 cells. The up-regulation of telomerase activity via phosphorylation of hTERT at a putative Akt phosphorylation site and association of hTERT with NFKB might play an important role in the neuroprotective functions of both estrogen and raloxifene. Solid and dashed lines indicate cellular and nuclear membranes respectively.

cancer (Mabuchi et al. 2004) cells. In addition, all membrane forms described to date are related to ER $\alpha$, and not to ER $\beta$ (Flouriot et al. 2000, Norfleet et al. 2000, Marquez $\&$ Pietras 2001). However, further studies are needed to clarify the role(s) of the individual ER isoforms in estrogen- or raloxifene-mediated neuroprotection.

Induction of telomerase activity via Akt might not be the only cascade involved in the neuroprotection by estrogen and raloxifene against $A \beta$-induced apoptosis. Much of the cellular damage caused by $A \beta$ can be attributed to dysregulation of calcium homeostasis. Because Bcl-2 plays a key role in mitochondrial $\mathrm{Ca}^{2+}$ regulation (Murphy et al. 1996), $\mathrm{E}_{2}$-induced attenuation of the increased mitochondrial sequestration of $\mathrm{Ca}^{2+}$ in response to excitotoxic glutamate is reported to be correlated with an increase in the expression of the anti-apoptotic gene bcl-2 (Nilsen \& Brinton 2003), which is also increased by $\mathrm{E}_{2}$ in vivo (Alkayed et al. 2001) and in vitro (Singer et al. 1998). These findings suggest the involvement of a genomic mechanism of the actions for estrogen in its neuroprotective effects.

\section{Acknowledgements}

We are grateful to Dr Monica M Oblinger (Chicago Medical School, North Chicago, USA) for PCCON and PCER cells. This work was supported in part by Grantsin-Aid for General Scientific Research, No 14571560 (to M O), No 14571538 (to N T) and No 14370523 (to $\mathrm{H} \mathrm{K}$ ), and in part by Grants-in-Aid for Center of Excellence (COE) 21 Program from the Ministry of Education, Culture, Sports, Science and Technology of Japan. The authors declare that there is no conflict of interest that would prejudice the impartiality of this scientific work.

\section{References}

Akiyama M, Hideshima T, Hayashi T, Tai YT, Mitsiades CS, Mitsiades N, Chauhan D, Richardson P, Munshi NC \& Anderson KC 2002 Cytokines modulate telomerase activity in a human multiple myeloma cell line. Cancer Research 62 3876-3882.

Akiyama M, Hideshima T, Hayashi T, Tai YT, Mitsiades CS, Mitsiades N, Chauhan D, Richardson P, Munshi NC \& Anderson 
KC 2003 Nuclear factor-kappaB p65 mediates tumor necrosis factor alpha-induced nuclear translocation of telomerase reverse transcriptase protein. Cancer Research 63 18-21.

Alkayed NJ, Goto S, Sugo N, Joh HD, Klaus J, Crain BJ, Bernard O, Traystman RJ \& Hurn PD 2001 Estrogen and Bcl-2: gene induction and effect of transgene in experimental stroke. Journal of Neuroscience 21 7543-7550.

Bondi MW, Salmon DP, Monsch AU, Galasko D, Butters N, Klauber MR, Thal LJ \& Saitoh T 1995 Episodic memory changes are associated with the APOE-epsilon 4 allele in nondemented older adults. Neurology 45 2203-2206.

Bonnefont AB, Munoz FJ \& Inestrosa NC 1998 Estrogen protects neuronal cells from the cytotoxicity induced by acetylcholinesterase-amyloid complexes. FEBS Letters 441 220-224.

Breitschopf K, Zeiher AM \& Dimmeler S 2001 Pro-atherogenic factors induce telomerase inactivation in endothelial cells through an Akt-dependent mechanism. FEBS Letters 493 21-25.

Cummings SR, Eckert S, Krueger KA, Grady D, Powles TJ, Jane A, Cauley LN, Nickelsen T, Bjarnason NH, Morrow M, Lippman ME, Black D, Glusman JE, Costa AV \& Jordan C 1999 The effect of raloxifene on risk of breast cancer in postmenopausal women: results from the MORE randomized trial. Multiple Outcomes of Raloxifene Evaluation. Journal of the American Medical Association 281 2189-2197.

Delmas PD, Bjarnason NH, Mitlak BH, Ravoux AC, Shah AS, Huster WJ, Draper M \& Christiansen C 1997 Effects of raloxifene on bone mineral density, serum cholesterol concentrations, and uterine endometrium in postmenopausal women. New England Journal of Medicine 337 1641-1647.

Dubal DB, Zhu H, Yu J, Rau SW, Shughrue PJ, Merchenthaler I, Kindy MS \& Wise PM 2001 Estrogen receptor alpha, not beta, is a critical link in estradiol-mediated protection against brain injury. PNAS 98 1952-1957.

Ettinger B, Black DM, Mitlak BH, Knickerbocker RK, Nickelsen T, Genant HK, Christiansen C, Delmas PD, Zanchetta JR, Stakkestad J, Glüer CC, Krueger K, Cohen FJ, Eckert S, Ensrud KE, Avioli LV, Lips P \& Cummings SR, for the Multiple Outcomes of Raloxifene Evaluation Investigators 1999 Reduction of vertebral fracture risk in postmenopausal women with osteoporosis treated with raloxifene: results from a 3-year randomized clinical trial. Journal of the American Medical Association 282 637-645.

Flouriot G, Brand H, Denger S, Metivier R, Ko M, Reid G, Sonntag-Buck V \& Gannon F 2000 Identification of a new isoform of the human estrogen receptor-alpha (hER-alpha) that is encoded by distinct transcripts and that is able to repress hER-alpha activation function 1. EMBO Journal 19 4688-4700.

Fu W, Killen M, Culmsee C, Dhar S, Pandita TK \& Mattson MP 2000 The catalytic subunit of telomerase is expressed in developing brain neurons and serves a cell survival-promoting function. Journal of Molecular Neuroscience 14 3-15.

Gollapudi L \& Oblinger MM 2001 Estrogen effects on neurite outgrowth and cytoskeletal gene expression in ERalpha-transfected PC12 cell lines. Experimental Neurology 171 308-316.

Greider CW \& Blackburn EH 1985 Identification of a specific telomere terminal transferase activity in Tetrahymena extracts. Cell 43 405-413.

Greider CW \& Blackburn EH 1989 A telomeric sequence in the RNA of Tetrahymena telomerase required for telomere repeat synthesis. Nature 337 331-337.

Harley CB \& Villeponteau B 1995 Telomeres and telomerase in aging and cancer. Current Opinion in Genetics and Development 5 249-255.

Hisamoto K, Ohmichi M, Kurachi H, Hayakawa J, Kanda Y, Nishio Y, Adachi K, Tasaka K, Miyoshi E, Fujiwara N, Taniguchi N \& Murata Y 2001a Estrogen induces the Akt-dependent activation of endothelial nitric-oxide synthase in vascular endothelial cells. Journal of Biological Chemistry 276 3459-3467.

Hisamoto K, Ohmichi M, Kanda K, Adachi K, Nishio Y, Adachi K, Hayakawa J, Mabushi S, Takahashi K, Tasaka K, Miyamoto Y,
Taniguchi N \& Murata Y $2001 b$ Induction of endothelial nitric-oxide synthase phosphorylation by the raloxifene analog LY117018 is differentially mediated by Akt and extracellular signal-regulated protein kinase in vascular endothelial cells. Journal of Biological Chemistry 276 47642-47649.

Honda K, Sawada H, Kihara T, Urushitani M, Nakamizo T, Akaike A \& Shimohama S 2000 Phosphatidylinositol 3-kinase mediates neuroprotection by estrogen in cultured cortical neurons. Journal of Neuroscience Research 60 321-327.

Kang SS, Kwon T, Kwon DY \& Do SI 1999 Akt protein kinase enhances human telomerase activity through phosphorylation of telomerase reverse transcriptase subunit. Journal of Biological Chemistry 274 13085-13090.

Kawagoe J, Ohmichi M, Takahashi T, Ohshima C, Mabuchi S, Takahashi K, Igarashi H, Mori-Abe A, Saitoh M, Du B, Ohta T, Kimura A, Kyo S, Inoue M \& Kurachi H 2003 Raloxifene inhibits estrogen-induced up-regulation of telomerase activity in a human breast cancer cell line. Journal of Biological Chemistry 278 43363-43372.

Kawas C, Resnick S, Morrison A, Brookmeyer R, Corrada M, Zonderman A, Bacal C, Lingle DD \& Metter E 1997 A prospective study of estrogen replacement therapy and the risk of developing Alzheimer's disease: the Baltimore Longitudinal Study of Aging. Neurology 48 1517-1521.

Kilian A, Bowtell DD, Abud HE, Hime GR, Venter DJ, Keese PK, Duncan EL, Reddel RR \& Jefferson RA 1997 Isolation of a candidate human telomerase catalytic subunit gene, which reveals complex splicing patterns in different cell types. Human Molecular Genetics 6 2011-2019.

Kim NW, Piatyszek MA, Prowse KR, Harley CB, West MD, Ho PL, Coviello GM, Wright WE, Weinrich SL \& Shay JW 1994 Specific association of human telomerase activity with immortal cells and cancer. Science 266 2011-2015.

Kimura A, Ohmichi M, Kawagoe J, Kyo S, Mabuchi S, Takahashi T, Ohshima, C, Arimoto-Ishida E, Nishio Y, Inoue M, Kurachi H, Tasaka K \& Murata Y 2004 Induction of hTERT expression and phosphorylation by estrogen via Akt cascade in human ovarian cancer cell lines. Oncogene 23 4505-4515.

Kyo S, Takakura M, Kanaya T, Zhuo W, Fujimoto K, Nishio Y, Orimo A \& Inoue M 1999 Estrogen activates telomerase. Cancer 59 5917-5921.

Li H, Zhao LL, Funder JW \& Liu JP 1997 Protein phosphatase 2A inhibits nuclear telomerase activity in human breast cancer cells. Journal of Biological Chemistry 272 16729-16732.

Li H, Zhao L, Yang Z, Funder JW \& Liu JP 1998 Telomerase is controlled by protein kinase $\mathrm{C}$ alpha in human breast cancer cells. Journal of Biological Chemistry 273 33436-33442.

Mabuchi S, Ohmichi M, Kimura A, Hisamoto K, Hayakawa J, Nishio Y, Adachi K, Takahashi K, Arimoto-Ishida E, Nakatsuji Y, Tasaka K \& Murata Y 2002 Inhibition of phosphorylation of BAD and Raf-1 by Akt sensitizes human ovarian cancer cells to paclitaxel. Journal of Biological Chemistry 277 33490-33500.

Mabuchi S, Ohmichi M, Kimura A, Ikebuchi Y, Hisamoto K, Arimoto-Ishida E, Nishio Y, Takahashi K, Tasaka K \& Murata Y 2004 Tamoxifen inhibits cell proliferation via mitogen-activated protein kinase cascades in human ovarian cancer cell lines in a manner not dependent on the expression of estrogen receptor or the sensitivity to cisplatin. Endocrinology 145 1302-1313.

Marquez DC \& Pietras RJ 2001 Membrane-associated binding sites for estrogen contribute to growth regulation of human breast cancer cells. Oncogene 20 5420-5430.

Meyerson M, Counter CM, Eaton EN, Ellisen LW, Steiner P, Caddle SD, Ziaugra L, Beijersbergen RL, Davidoff MJ, Liu Q, Bacchetti S, Haber DA \& Weinberg RA 1997 hEST2, the putative human telomerase catalytic subunit gene, is up-regulated in tumor cells and during immortalization. Cell 90 785-795. 
Miech RA, Breitner JC, Zandi PP, Khachaturian AS, Anthony JC \& Mayer L 2002 Incidence of AD may decline in the early 90s for men, later for women: The Cache County study. Neurology 58 209-218.

Murphy AN, Bredesen DE, Cortopassi G, Wang E \& Fiskum G 1996 Bcl-2 potentiates the maximal calcium uptake capacity of neural cell mitochondria. PNAS 93 9893-9898.

Nakamura TM, Morin GB, Chapman KB, Weinrich SL, Andrews WH, Lingner J, Harley CB \& Cech TR 1997 Telomerase catalytic subunit homologs from fission yeast and human. Science $\mathbf{2 7 7}$ 955-959.

Nilsen J \& Brinton RD 2003 Mechanism of estrogen-mediated neuroprotection: regulation of mitochondrial calcium and Bcl-2 expression. PNAS 100 2842-2847.

Nilsen J, Mor G \& Naftolin F 1998 Raloxifene induces neurite outgrowth in estrogen receptor positive PC12 cells. Menopause $\mathbf{5}$ 211-216.

Norfleet AM, Clarke CH, Gametchu B \& Watson CS 2000 Antibodies to estrogen receptor-alpha modulate rapid prolactin release from rat pituitary tumor cells through plasma membrane estrogen receptors. FASEB Journal 14 157-165.

Paganini-Hill A \& Henderson VW 1996 Estrogen replacement therapy and risk of Alzheimer disease. Archives of Internal Medicine $1562213-2217$.

Rapp SR, Espeland MA, Shumaker SA, Henderson VW, Brunner RL, Manson JE, Gass ML, Stefanick ML, Lane DS, Hays J, Johnson KC, Coker LH, Dailey M, Bowen D, WHIMS Investigators 2003 Effect of estrogen plus progestin on global cognitive function in postmenopausal women: the Women's Health Initiative Memory Study: a randomized controlled trial. Journal of the American Medical Association 289 2663-2672.

Shay JW \& Bacchetti S 1997 A survey of telomerase activity in human cancer. European Journal of Cancer 33 787-791.

Shumaker SA, Legault C, Rapp SR, Thal L, Wallace RB, Ockene JK, Hendrix SL, Jones BN 3rd, Assaf AR, Jackson RD, Kotchen JM, Wassertheil-Smoller S, Wactawski-Wende J, WHIMS Investigators 2003 Estrogen plus progestin and the incidence of dementia and mild cognitive impairment in postmenopausal women: the Women's Health Initiative Memory Study: a randomized controlled trial. Journal of the American Medical Association 289 2651-2662.

Singer CA, Rogers KL \& Dorsa DM 1998 Modulation of Bcl-2 expression: a potential component of estrogen protection in NT2 neurons. Neuroreport 9 2565-2568.

Skoog I \& Gustafson D 1999 HRT and dementia. Journal of Epidemiology Biostatistics 4 227-251.

Tang MX, Jacobs D, Stern Y, Marder K, Schofield P, Gurland B, Andrews H \& Mayeux R 1996 Effect of oestrogen during menopause on risk and age at onset of Alzheimer's disease. Lancet 348 429-432.

Yaffe K, Krueger K, Sarkar S, Grady D, Barrett-Connor E, Cox DA \& Nickelsen T, Multiple Outcomes of Raloxifene Evaluation Investigators 2001 Cognitive function in postmenopausal women treated with raloxifene. New England Journal of Medicine 344 1207-1213.

Zandi PP, Carlson MC, Plassman BL, Welsh-Bohmer KA, Mayer LS, Steffens DC, Breitner JC, Cache County Memory Study Investigators 2002 Hormone replacement therapy and incidence of Alzheimer disease in older women: the Cache County study. Journal of the American Medical Association 288 2123-2129.

Zhang L, Rubinow DR, Xaing G, Li BS, Chang YH, Maric D, Barker JL \& Ma W 2001 Estrogen protects against beta-amyloid-induced neurotoxicity in rat hippocampal neurons by activation of Akt. Neuroreport 12 1919-1923.

Zhu H, Fu W \& Mattson MP 2000 The catalytic subunit of telomerase protects neurons against amyloid beta-peptide-induced apoptosis. Journal of Neurochemistry 75 117-124.

Received 13 August 2004

Accepted 19 August 2004

Made available online as an

Accepted Preprint 27 August 2004 